\title{
Pengaruh Keselamatan dan Kesehatan Kerja Terhadap Kinerja Karyawan
} PT PP Presisi, Tbk Proyek Tol Manado-Bitung

\author{
Pemsi Kourouw \\ Ventje Tatimu \\ Sofia A. P. Sambul \\ Prodi Studi Ilmu Administrasi Bisnis, Jurusan Ilmu Administrasi, \\ Fakultas Ilmu Sosial dan Politik, Universitas Sam Ratulangi Manado \\ Email:pemsi.kourouw20@gmail.com
}

\begin{abstract}
This study aims to determine the effect of Occupational Safety and Health on Employees Performance at PT. PP Presisi .Tbk Proyek Tol Manado-Bitung. This study uses a quantitative approach, with a sample of 70 respondents. The sampling techniques in this study were to use Simple Random Samplimg. Data collection techniques in this study are by using a questionnaire distribution. The analysis techniques used in this study includes validity test, reliability test, multiple regression test, $F$ test, $t$ test and coefficient of determination. The data that has fulfilled the analysis techniques was processed using the help of the SPSS 25 program. It can be seen from the results of the statistical test that the Occupational Safety and Health independent variables affect the dependent variable of Employee Performance. The results showed that based on the calculation of the coefficient of determination the influence of the independent variable Occupational Safety and Health on the dependent variable of Employee Performance is 0,368 or 3,68 \% which shows that Employee Performance can be influenced by Occupational Safety variable and Occupational Health variable. While the remaining 63, $2 \%$ is influenced by other variables that do not exist in this study. This shows that Occupational Safety and Health has a significant effect on Employee Performance. Where if Occupational Safety is guaranteed and Occupational Health is good will improve Employee Performance.
\end{abstract}

Keywords: Occupational Safety, Occupational Health and Employee Performance.

\section{Pendahuluan}

Dalam menjalankan suatu bisnis, perusahaan membutuhkan sumber daya manusia, yaitu karyawan. Sumber daya manusia dalam hal ini karyawan tidak lepas dari masalah yang berkaitan dengan keselamatan dan kesehatan kerja. Dengan keselamatan dan kesehatan kerja yang terjamin maka dapat menumbuhkan semangat kerja pada karyawan. Karyawan yang bekerja memiliki hak atas keselamatan dan kesehatan yang pelaksanaannya dilandasi oleh peraturan perundang-undang. Keselamatan dan Kesehatan Kerja (K3) selain bertujuan untuk mengurangi angka kecelakaan kerja, juga dijadikan sebagai aspek perlindungan tenaga kerja sekaligus melindungi asset perusahaan untuk sedapat mungkin memberikan jaminan kondisi yang aman 
dan sehat kepada setiap karyawan untuk melindungi Sumber Daya Manusia (SDM) di Indonesia khususnya di PT PP Presisi .Tbk Proyek Tol Manado-Bitung.

Masalah keselamatan kerja di Indonesia masih sering diabaikan, hal ini dapat dilihat dari masih tingginya angka kecelakaan kerja. Badan Penyelenggara Jaminan Sosial (BPJS) Ketenagakerjaan mencatat, pada tahun 2017 angka kecelakaan kerja yang dilaporkan mencapai 123.041 kasus, sementara sepanjang 2018 mencapai 173.105 kasus. Selain itu, data dari International Labour Organization (ILO) juga turut mencatat, setiap hari terjadi sekitar 6.000 kecelakaan kerja fatal di dunia. Di Indonesia sendiri, terdapat kasus kecelakaan yang setiap harinya dialami para buruh dari setiap 100 ribu tenaga kerja dan $30 \%$ diantaranya terjadi di sector konstruksi. Pemerintah sendiri sangat sadar tentang betapa pentingnya keselamatan dan kesehatan kerja, ini dapat dilihat dalam aturan yang dimuat dalam Undang-Undang Republik Indonesia No. 13 Tahun 2003, Paragraf 5, Pasal 86 No. 1a tentang Keselamatan dan Kesehatan kerja yang isinya sebagai berikut. "setiap pekerja/buruh mempunyai hak untuk memperoleh perlindungan atas keselamatan dan kesehatan kerja."

Keselamatan dan Kesehatan Kerja (K3) adalah suatu kegiatan yang menjamin terciptanya kondisi kerja yang aman, terhindar dari gangguan fisik dan mental melalui pembinaan dan pelatihan, pengarahan dan kontrol terhadap pelaksanaan tugas dari para karyawan dan pemberian bantuan sesuai dengan aturan yang berlaku, baik dari lembaga pemerintah maupun perusahaan dimana mereka bekerja Yuli (2005:211). Selain itu, keselamatan dan kesehatan kerja merupakan hal yang seyogyanya menjadi perhatian suatu perusahaan Sundah (2018:139). Menurut Undang-Undang Pokok Kesehatan RI No. 9 Tahun 1960, Bab 1 pasal 2 menyatakan bahwa "Yang dimaksud dengan kesehatan dalam Undang-undang ini ialah yang meliputi kesehatan badan, rohani, (mental) dan sosial, dan bukan hanya keadaan yang bebas dari penyakit, cacat dan kelemahan". Hal ini untuk menciptakan terwujudnya pemeliharaan karyawan dengan baik. Disamping itu pula, hal ini merupakan usaha untuk mempertahankan karyawan yang sudah ada. Dengan adanya program keselamatan dan kesehatan kerja bagi karyawan akan membantu memelihara kondisi fisik para karyawan, sedangkan program pelayanan karyawan akan membantu memelihara sikap karyawan. Terjadinya kecelakaan atau penyakit saat bekerja yang dapat berakibat kematian, atau karyawan bisa mengalami cacat atau sakit untuk sementara dan tidak bisa bekerja, 
maka karyawan tersebut tidak akan mampu lagi bekerja dengan baik atau tingkat produktivitas kerjanya akan mengalami penurunan dibanding waktu mereka sehat. Oleh sebab itu perlu system pemberian kompensasi akibat kecelakaan kerja untuk meningkatkan kinerja karyawan.

Kinerja karyawan yang baik dapat memberikan dampak yang baik bagi perusahaan secara keseluruhan. Dapak positifnya adalah peningkatan penyelesaian tanggung jawab yang diberikan perusahaan bagi karyawan. Kinerja adalah "sesuatu yang ditampilkan oleh seseorang atau suatu proses yang berkaitan dengan tugas kerja yang ditetapkan, Amir (2015:5). Kinerja bukan ujung terakhir dari serangkaian sebuah proses kerja tetapi tampilan keseluruhan yang dimulai dari unsur kegiatan input, proses, output, dan bahkan outcome". Salah satu faktor yang mempengaruhi kinerja karyawan ialah faktor keamanan dan perlindungan pada saat bekerja. Ketika karyawan merasa aman dan nyaman karena mendapatkan perlindungan dari perusahaan, maka karyawan tersebut juga akan bekerja dengan perasaan yang tenang dan akan bekerja dengan baik agar memiliki prestasi kerja yang maksmimal. Salah satu upaya dalam menerapkan perlindungan terhadap karyawan adalah dengan melaksanakan program Keselamatan dan Kesehatan Kerja
(K3). Kinerja merupakan sebuah proses untuk menciptakan suatu produk atau jasa yang dilakukan oleh sekelompok orang dalam sebuah perusahaan. Suatu kinerja yang baik tentunya akan memberikan hasil yang baik pula bagi suatu perusahaan. Kinerja merupakan aspek yang penting bagi sebuah perusahaan. Karena maju atau mundurnya sebuah perusahaan akan ditentukan oleh hal ini. Jika para karyawan berkinerja buruk maka yang terjadi adalah kemerosotan pada perusahaannya. Sebaliknya, jika para karyawan tersebut senang berinovasi, rajin dan memenuhi setiap yang diamanahkan suatu perusahaan maka yang terjadi adalah kemajuan yang positif bagi perusahaannya.

PT. PP Presisi .Tbk mrupakan perusahaan konstruksi terintegrasi berbasis alat berat terkemuka di Indonesia yang memiliki kapabilitas untuk menyediakan jasa konstruksi dari 7 lini bisnis yaitu civil work, ready mix, foundation, form work, penyewaan alat berat, erector dan jasa pertambangan secara terintegrasi yang memberikan nilai tambah kepada para konsumen. PT. PP Presisi .Tbk saat ini menjadi salah satu perusahaan jasa konstruksi yang sedang mengerjakan proyek strategis nasional milik pemerintah yaitu jalan tol Manado-Bitung sepanjang 39 kilometer yang akan meningkatkan konektivitas dari kota Manado ke 
pelabuhan hubungan internasional Bitung. PT. PP Presisi .Tbk berkomitmen untuk terus mengembangkan bisnisnya dibidang konstruksi dengan menyediakan kebutuhan pelanggan dalam satu tempat (one stop service), mengetahui kebutuhan pelanggan dan meningkatkan pelayanan di semua bidang konstruksi.

Dengan melihat PT. PP Presisi .Tbk sebagai perusahaan yang bergerak pada jasa konstuksi maka para karyawan pasti akan terlibat dalam banyak kegiatan yang dapat menghadapkan mereka dengan bahaya yang serius, seperti jatuh dari ketinggian, mesin yang tidak dijaga, terkena peralatan konstuksi berat, listrik, terpapar oleh bahan material yang berbahaya, dan debu dari lingkungan pekerjaan.

Dengan demikian karyawan harus memndapatkan perhatian yang khusus oleh pihak perusahaan. Karena manusia merupakan asset utama yang harus diperhatikan dan di kelola dengan baik agar sumber daya manusia yang dimiliki perusahaan mampu bekerja secara optimal dalam upaya pencapaian tujuan organisasi. Dalam pengelolaan sumber daya manusia diperlukan manajemen yang mampu melindungi, mencegah dan meminimalisir karyawan dari kecelakaan kerja. Salah satu yang harus menjadi perhatian utama bagi manajer sumber daya manusia ialah keselamatan dan kesehatan kerja. Manajemen keselamatan dan kesehatan pada perusahaan inilah yang diharapkan mampu mewujudkan karyawan yang lebih aman dan kompetitif. Dengan terlaksananya manajemen keselamatan dan kesehatan dengan baik maka tentunya akan berdampak positif baik bagi para karyawan maupun bagi kinerja perusahaan.

Hal inilah yang menjadi alasan bagi penulis untuk memilih PT. PP Presisi di Proyek Tol Manado-Bitung menjadi lokasi penelitian, dimana dalam proses memenuhi kebutuhan konsumen kemungkinan besar memiliki resiko tinggi akan bahaya-bahaya yang muncul dan yang terutama alasannya karena penulis mengetahui bahwa PT. PP Presisi sudah melaksanakan Keselamatan dan Kesehatan Kerja (K3).

Berdasarkan data dan uraian diatas, maka penulis tertarik untuk melakukan penelitian dengan judul "Pengaruh Keselamatan dan Kesehatan Kerja Terhadap Kinerja Karyawan Pada PT. PP Presisi di Proyek Tol Manado-Bitung”.

\section{Tinjauan Pustaka}

\section{Keselamatan Kerja}

Masalah keselamatan kerja merupakan suatu hal yang sangat penting, karena dapat menciptakan lapangan kerja yang aman, tenang dan tentram, maka karyawan yang bekerja pun akan 
bersemangat dan dapat bekerja dengan baik sehingga hasil kerjanya memuaskan. Keselamatan kerja menunjukan kondisi yang aman atau selamat dari penderitaan, kerusakan atau kerugian ditempat kerja, Mangkunegara (2013:161). Resiko keselamatan merupakan aspek-aspek dari lingkungan kerja yang dapat menyebabkan kebakaran, luka memar, keseleo, patah tulang, gangguan penglihatan dan pendengaran. Sesuai dengan pengertian keselamatan kerja yang dikemukakan diatas maka indikator-indikator dari keselamatan kerja menurut Moenir (1983 : 203) adalah : (1). Lingkungan kerja secara fisik. Penempatan benda/ barang sedemikian rupa sehingga tidak membahayakan/ mencelakakan orang-orang yang berada ditempat kerja/ disekitarnya. Penempatan dapat pula dilakukan dengan diberi tanda, batas-batas \& peringatan yang cukup; (2) Lingkungan sosial psikologis. Sedangkan jaminan keselamatan kerja secara psikologis dapat dilihat pada aturan organisasi sepanjang mengenai berbagai jaminan lihat pada aturan organisasi sepanjang mengenai berbagai jaminan organisasi atas pegawai/ pekerja.

\section{Kesehatan Kerja}

Kesehatan kerja merupakan suatu usaha yang dilakukan oleh suatu organisasi untuk memelihara kesehatan para karyawan bertujuan agar dapat mempertahankan produktivitas kerja perusahaan serta menekan tingkat absensi yang tinggi. Kesehatan kerja merujuk pada kondisi fisik, mental, dan stabilitas emosi secara umum, Mathis (2002:245). Seseorang yang sehat adalah yang bebas dari penyakit, cedera serta masalah mental dan emosi yang bisa mengganggu aktivitas manusia normal pada umumnya. Adapun indikator-indikator dari kesehatan kerja adalah sebagai berikut, Manullang (2000:87): (1). Lingkungan kerja secara medis.; (2). Sarana kesehatan tenaga kerja.; (3). Pemeliharaan kesehatan tenaga kerja.

\section{Kinerja Karyawan}

Kinerja adalah tingkat pencapaian hasil atas pelaksanaan tugas tertentu, Simanjuntak (dalam Pio, 2015: 255). Selain itu, kinerja adalah hasil kerja yang dapat dicapai oleh seseorang atau sekelompok orang dalam suatu organisasi, sesuai dengan wewenang dan tanggung jawab masing-masing dalam rangka upaya mencapai tujuan organisasi bersangkutan secara legal, tidak melanggar hukum dan sesuai dengan moral maupun etika, Prawirosentono (dalam Rumawas 2018: 131). Terdapat tiga indikator yang digunakan dalam rangka pengukuran kinerja para karyawan atau pegawai pada perusahaan menurut Mangkunegara 
(2011:69) yaitu: (1). Mutu atau Kualitas

Produk. Pada pengukuran ini perusahaan lebih mendasarkan pada tingkat kualitas produk yang telah dihasilkan para pegawai tau karyawannya.; (2). Kuantitas atau Jumlah Produk. Pengukuran melalui kuantitas atau jumlah produk yang dihasilkan ini erat kaitannya dengan kemampuan seseorang karyawan dalam menghasilkan produk dalam jumlah tertentu.; (3). Ketepatan Waktu. Ketepatan waktu dalam menyelesaikan suatu produk menjadi salah satu sarana untuk mengukur tingkat kinerja yang telah dicapai oleh seorang pegawai.

\section{Kerangka Pemikiran}

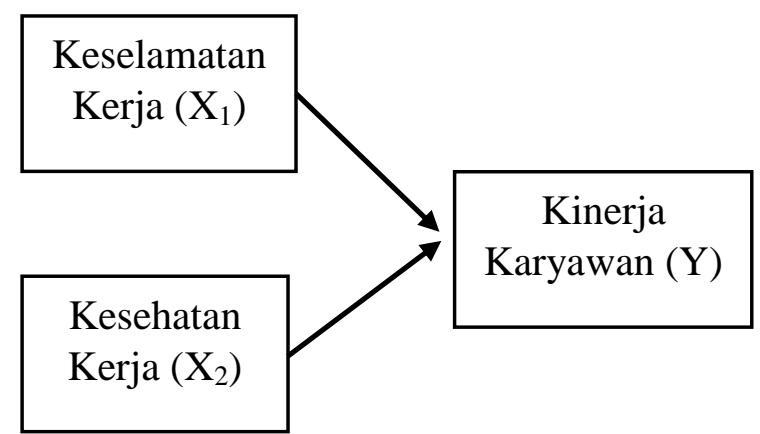

Keamanan dalam bekerja akan membuat karyawan merasa nyaman dan betah dalam bekerja. Hal ini dapat menimbulkan semangat karyawan dalam bekerja sehingga dapat meningkatkan kinerja karyawan. Maka diperlukan K3 (keselamatan dan kesehatan kerja) untuk meningkatkan kinerja karyawan. Karena bila adanya jaminan tersebut maka, karyawan akan lebih meningkat kinerjanya.

\section{Metode Penelitian}

Penelitian ini menggunakan pendekatan kuantitatif dan menggunakan teknik analisis regresi berganda dibantu dengan program SPSS. Metode kuantitatif yaitu suatu metode yang menggunakan sistem pengambilan sampel dari suatu populasi dan menggunakan kuesioner terstruktur sebagai alat pengumpulan data. Selanjutnya agar jawaban responden dapat diukur maka jawaban responden diberi skor. Dalam pemberian skor maka digunakan skala Likert.

\section{Hasil Penelitian}

(1). Pengaruh Keselamatan Kerja Terhadap Kinerja Karyawan. Hasil uji validitas pada variabel keselamatan kerja $\left(X_{1}\right) 6$ item pernyataan dinyatakan valid dimana diperoleh nilai $R_{\text {hitung }}>R_{\text {tabel }}$, kemudian hasil uji realibilitas diperoleh nilai cronbach alpha > 0,60 yaitu 0,767 maka data tersebut reliable atau dapat digunakan sebagai bahan penelitian. Berdasarkan hasil regresi linier berganda pada koefisien regresi variabel keselamatan kerja memiliki pengaruh positif dimana nilai koefisien regresi 0,152 hal ini menunjukan bahwa pelaksanaan program keselamatan kerja di PT. PP Presisi .Tbk Proyek Tol ManadoBitung sudah baik sehingga kinerja karyawan meningkat. Hasil analisis Uji Parsial (Uji-t) diperoleh $t_{\text {hitung }}$ variabel 
keselamatan kerja $\left(\mathrm{X}_{1}\right)$ adalah sebesar 1.071 dengan signifikansi 0,000. Dimana nilai signifikansi uji-t yang lebih kecil $(<)$ dari 0,05 sehingga hipotesis pertama diterima yang menyatakan bahwa keselamatan kerja $\left(\mathrm{X}_{1}\right)$ berpengaruh positif terhadap kinerja karyawan PT. PP Presisi Tbk Proyek Tol Manado-Bitung; (2). Pengaruh Kesehatan Kerja Terhadap Kinerja Karyawan. Hasil uji validitas pada variabel kesehatan kerja $\left(\mathrm{X}_{1}\right) \quad 6$ item pernyataan dinyatakan valid dimana diperoleh nilai $t_{\text {hitung }}>t_{\text {tabel }}$, kemudian hasil uji realibilitas diperoleh nilai cronbach alpha > 0,60 yaitu 0,766 maka data tersebut reliable, berdasarkan hasil regresi linier berganda variabel keselamatan kerja memiliki pengaruh positif dimana nilai koefisien regresi 0,448 . Hasil analisis Uji Parsial (Uji-t) diperoleh $t_{\text {hitung }}$ untuk variabel kesehatan kerja 3.534 dengan signifikansi 0,001 dimana hasil tersebut nilai signifikansinya lebih kecil dari 0,05 yang menunjukan hipotesis kedua juga diterima yang menyatakan kesehatan kerja $\left(\mathrm{X}_{2}\right)$ berpengaruh positif terhadap kinerja karyawan PT. PP Presisi .Tbk Proyek Tol Manado-Bitung; (3). Pengaruh Keselamatan kerja dan Kesehatan Kerja Terhadap Kinerja Karyawan. Hasil perhitungan koefisien determinan diketahui besarnya pengauh variabel keselamatan kerja dan kesehatan kerja terhadap kinerja karyawan sebesar 0,368 atau $36,8 \%$ sedangkan sisanya dipengaruhi faktor lain yang tidak ada dalam penelitian ini, Kemudian berdasarkan tabel interpretasi koefisien korelasi diketahui nilai R-square 0,368 yang menyatakan variabel keselamatan kerja dan variabel kesehatan kerja memiliki hubungan yang rendah terhadap variabel kinerja karyawan. Kemudian berdasarkan hasil $t_{\text {hitung }}$ dari kedua variabel, yang paling besar mempengaruhi kinerja karyawan PT. PP Presisi .Tbk Proyek Tol Manado-Bitung yaitu variabel kesehatan kerja $\left(\mathrm{X}_{2}\right)$ yang memperoleh nilai $t_{\text {hitung }}$ lebih tinggi $=$ 3.534. Berdasarkan hasil tabel diatas diperoleh nilai $F_{\text {hitung }}>F_{\text {tabel }}$ atau 19.517 lebih besar dari 3,13 maka dapat disimpulkan keselamatan kerja $\left(\mathrm{X}_{1}\right)$ dan kesehatan kerja $\left(\mathrm{X}_{2}\right)$ secara simultan (bersama-sama) berpengaruh secara signifikan terhadap kinerja karyawa pada PT. PP Presisi .Tbk Proyek Tol Manado Bitung.

\section{Pembahasan Penelitian}

Berdasarkan hasil penelitian pada item-item variabel, (1). keselamatan kerja menunjukan bahwa sebagian besar karyawan PT. PP Presisi Tbk Proyek Tol Manado-Bitung sangat mengapresiasi dengan adanya semua peralatan kerja dalam perusahaan dengan kondisi baik dan 
layak pakai sehingga keselamatan kerja terjamin dan juga dapat meningkatkan kinerja karyawan; (2). Kesehatan kerja menunjukan bahwa sebagian besar karyawan PT. PP Presisi Tbk Proyek Tol Manado-Bitung sangat mengapresiasi dengan adanya kebijakan Perusahaan dalam menyediakan pelayanan pemeriksaan kesehatan bagi setiap karyawan sehingga kesehatan para karyawan terjamin dalam bekerja diperusahaan tersebut; (3). Kinerja karyawan menunjukan bahwa sebagian besar karyawan PT. PP Presisi Tbk Proyek Tol Manado-Bitung memiliki semangat kerja yang tinggi dalam bekerja diperusahaan tersebut. Berdasarkan perhitungan analisis koefisien regresi pada variabel keselamatan kerja menunjukan bahwa keselamatan kerja mempengaruhi kinerja karyawan sebesar 0,152 dimana artinya variabel keselamatan kerja berpengaruh positif terhadap kinerja karyawan dan mengalami peningkatan sebesar 0,152 sehingga, kinerja karyawan akan meningkat secara linier berganda 0,152. Sedangkan pada variabel kesehatan kerja mempengaruhi kinerja karyawan sebesar 0,448 yang artinya variabel kesehatan kerja (X2) berpengaruh positif terhadap kinerja karyawan dan mengalami peningkatan sebesar 0,448 sehingga kinerja karyawan akan meningkat secara linier berganda sebesar 0,448. Artinya apabila terjadi kenaikan keselamatan dan kesehatan kerja maka akan menyebabkan kenaikan juga pada kinerja karyawan PT PP Presisi .Tbk Proyek Tol Manado-Bitung begitupun sebaliknya. Kemudian berdasarkan hasil koefisien determinasi memiliki nilai $\mathrm{R}$ Square sebesar 0,368 atau sebesar $36,8 \%$ yang menunjukan bahwa kinerja karyawan dapat dipengaruhi oleh variabel keselamatan kerja dan variabel kesehatan kerja. Sedangkan sisanya sebanyak $63,2 \%$ dipengaruhi oleh variabel lain yang tidak ada dalam penelitian ini.

\section{Simpulan}

Berdasarkan hasil penelitian terdapat beberapa kesimpulan dari hasil penelitian yaitu sebagai berikut : (1). Berdasarkan analisis regresi berganda bahwa variabel keselamatan kerja berpengaruh positif terhadap kinerja karyawan PT. PP Presisi .Tbk Proyek Tol Manado-Bitung. Dan berdasarkan Uji-t diperoleh untuk variabel keselamtan dan kesehatan kerja dengan nilai signifikansi lebih kecil yang menunjukan hipotesis pertama diterima yang menyatakan keselamatan kerja berpengaruh positif terhadap kinerja karyawan PT. PP Presisi .Tbk Proyek Tol Manado-Bitung. Hal ini menunjukan keselamatan kerja karyawan dijaga oleh pihak perusahaan dengan menerapkan pelatihan, pemeliharaan peralatan, 
Jurnal Administrasi Bisnis (JAB)

Vol. 9. No. 3, 2019

(p-ISSN 2338-9605; e-2655-206X)

ketersediaan pertolongan saat terjadi karyawannya terbukti dengan adanya hasil kecelakaan serta asuransi sehingga karyawan lebih produktif dalam melakukan pekerjaannya dan terhindar dari kecelakaan ditempat kerja; (2). Berdasarkan analisis regresi berganda bahwa variabel kesehatan kerja berpengaruh positif terhadap kinerja karyawan PT. PP Presisi .Tbk Proyek Tol Manado-Bitung. Dan berdasarkan Uji-t diperoleh untuk variabel keselamtan dan kesehatan kerja dengan nilai signifikansi lebih kecil yang menunjukan hipotesis kedua juga diterima yang menyatakan kesehatan kerja berpengaruh positif terhadap kinerja karyawan PT. PP Presisi .Tbk Proyek Tol Manado-Bitung. Hal ini menunjukan kesehatan kerja karyawan diutamakan oleh pihak perusahaan dengan memberikan makanan yang bergizi, lingkungan pekerjaan yang bersih, adanya pemeriksaan kesehatan, adanya sarana olaraga dan rekreasi sehingga meningkatkan semangat karyawan dalam bekerja dan resiko terkena sakit atau stress saat bekerja berkurang.

Berdasarkan kesimpulan diatas dapat dikemukakan beberapa saran yang nantinya dapat dimanfaatkan bagi perusahaan maupun bagi peneliti selanjutnya, adapun saran yang diberikan adalah sebagai berikut: (1). Kepada PT. PP Presisi Tbk Proyek Tol Manado-Bitung sebaiknya lebih memperhatikan kesehatan para penelitian bahwa kesehatan kerja lebih besar berperngaruh terhadap kinerja karyawan. Dan diharapkan perusahaan lebih memperbaiki tata kelola Keselamatan dan Kesehatan Kerja agar hal-hal yang tidak diharapkan seperti kecelakaan dan sakit ditempat kerja tidak terjadi dan kinerja karyawan lebih optimal; (2). Bagi peneliti selanjutnya diharapkan penelitian ini dapat menjadi informasi atau bahan masukan untuk melakukan penelitian yang berkaitan dengan variabel keselamatan kerja dan kesehatan kerja serta variabel lain yang tidak ada dalam penelitian ini yang juga berpengaruh dalam meningkatkan kinerja karyawan.

\section{Referensi}

Amir, M, F. (2015). Memahami Evaluasi Kinerja Karyawan. Jakarta: Mitra Wacana Media.

Mathis, R, L. dan Jackson, J, H. (2002). Manajemen Sumber Daya Manusia. Jakarta:Salemba Empat.

Mangkunegara, A. P. (2013). Manajemen sumber daya manusia perusahaan. Bandung: PT Remaja Rosdakarya.

Manullang, M. \& Manullang, M, A. (2000). Manajemen Personalia. Yogyakarta: Gadjah Mada University Press.

Pio, R, J. (2015). Kepemimpinan Spiritual, Dimensi-Dimensi Sumber Daya Manusia. Manado: Kepel Press. 
Jurnal Administrasi Bisnis (JAB)

Vol. 9. No. 3, 2019

(p-ISSN 2338-9605; e-2655-206X)

Rumawas, W. (2018). Manajemen Sumber

Daya Manusia. Manado: Unsrat Press.

Sundah, D, I, E. (2018). Manajemen

Sumber Daya Manuisa. PT. Manado: Percikan Hati.

Yuli, S, B, C. (2005). Manajemen Sumber Daya Manusia. Malang:UMM Press.

Undang-Undang Republik Indonesia Nomor 13 Tahun 2003 Tentang Ketenagakerjaan. 